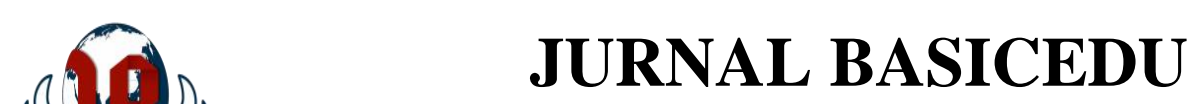

Volume 5 Nomor 3 Tahun 2021 Halaman 1593 - 1603

Research \& Learning in Elementary Education

https://jbasic.org/index.php/basicedu

PAHLAWAN

\title{
Playing Football Creating Education Character In Youth Perspective In Nighborhood Environment
}

\author{
Bahagia $^{1 凶}$, Rimun Wibowo ${ }^{2}, Z$ ulkifli Rangkuti ${ }^{3}, Z^{2}$ akky Muhammad Noor ${ }^{4}$ \\ Universitas Ibn Khaldun Bogor, Indonesia ${ }^{1}$ \\ STIMA IMMI Jakarta, Indonesia ${ }^{2,3}$ \\ LPM Equator Bogor, Indonesia ${ }^{4}$ \\ E-mail: bahagiagia59@yahoo.co.id ${ }^{1}$, rimunwibowo@gmail.com² ${ }^{2}$, zrangkuti@gmail.com² \\ zakkymdnr@gmail.com ${ }^{4}$
}

\begin{abstract}
Abstrak
Penelitian ini bertujuan untuk mengetahui nilai karakter dalam bermain sepak bola dari perspektif remaja di pada team pemain sepak bola pada tingkat rukun tetangga. Pendekatan metode penelitian menggunakan pendekatan kualitatif dan etnografi. Metode tersebut tersirat karena penelitian ini bertujuan untuk mengetahui nilai karakter dalam permainan sepak bola berdasarkan perspektif masyarakat pada Remaja team sepak bola rukun tetangga. Data dikumpulkan dengan wawancara mendalam. Sampel dipilih melalui teknik purposive. Hasilnya diteliti dengan cermat melalui teknik triangulasi dan triangulasi sumber. Hasil penelitian menunjukkan bahwa bermain sepak bola memiliki banyak nilai dalam pembentukan karakter diantaranya adalah kerjasama tim, kejujuran, tanggung jawab, peran dalam masyarakat, dan nilai sportif. Kedua, bermain sepak bola memiliki nilai modal sosial karena pertandingan sepak bola membangun jejaring sosial, saling percaya, solidaritas, gotong royong dan hubungan sosial antar anggota dalam kelompok atau kelompok pesaing. Temuan lain yaitu menghilangkan beberapa penyakit seperti serangan jantung, obesitas, menghilangkan tingkat stres manusia, dan penyakit paruparu. Terakhir, dapat meningkatkan kesejahteraan masyarakat sekitar karena masyarakat memiliki kesempatan untuk berdagang sebagian makanan dan minuman saat pertandingan sepak bola digelar.
\end{abstract}

Kata Kunci: Karakter, Pendidikan, permainan sepak bola, pemuda

\begin{abstract}
The objective of this research is to discover character value in playing football from a youth perspective in the neighborhood football team. The research method approach exerts qualitative and ethnographic. The method is implied because the research intends to find out character value in football playing based on community perspective in neighborhood football group. The data are gathered with an in-depth interview. Sample are selected through purposive technique. The result is probed meticulously through the triangulation technique and triangulation sources. The result shows that playing football has numerous values in creating character including teamwork, honesty, responsibility, role in society, and Sportif value. The other is playing football have social capital value because football match creating social networking, trusting, solidarity, mutual assisting and social connection among the member in group or group of a competitor. The other is to vanish some of the ailment such as heart attack, obesity, abolish the rate of human stress, and lung ailment. Lastly, it can improve the prosperity of societies around because the community has the opportunity to trade some of the meal and drink when the football is conducted.
\end{abstract}

Keywords: Character, education, football-matching, youth

Copyright (c) 2021 Bahagia, Rimun Wibowo, Zulkifli Rangkuti, Zakky Muhammad Noor

$\triangle$ Corresponding author :

Email : bahagiagia59@yahoo.co.id

DOI $\quad$ : https://doi.org/10.31004/basicedu.v5i3.934

ISSN 2580-3735 (Media Cetak)

ISSN 2580-1147 (Media Online)

Jurnal Basicedu Vol 5 No 3 Tahun 2021

p-ISSN 2580-3735 e-ISSN 2580-1147 
1594 Playing Football Creating Education Character In Youth Perspective In Nighborhood Environment Bahagia, Rimun Wibowo, Zulkifli Rangkuti, Zakky Muhammad Noor

DOI: https://doi.org/10.31004/basicedu.v5i3.934

\section{INTRODUCTION}

Moral damage has begun to appear in the present. Suryadi, (2012) said that the character of the nation which has decreased from time to time has become a serious topic of discussion, starting from the common people to officials and heads of state. The character of the nation has not only become a local and national issue but has also become a global issue. One of the causes of character damage is due to the progress of the times. Jahroh \& Sutarna, (2016) said that the advancement of technological knowledge that should be able to create civil society erodes the importance of politeness values, good teachings about deeds and behavior (akhlaq), or what we often call morals. Laksana, (2015) remarked that the various problems that often occur in children's character education are the occurrence of behavior deviations both on a large and small scale such as brawls between students, violations of driving rules, abuse of illegal drugs, free sex, and violations of Discipline violations in schools have become commonplace in schools and there are still many phenomena or cases that show that the moral character of this nation is experiencing unsteadiness. This fact is also supported by other opinions that character damage consists of fights between students, the number of drug cases that ensnare students, students who show disrespect for adults, cases of cheating that have become a habit (Siswanti et al., 2018).

Wahidin, (2017) problems that arise in society such as violence committed by teenagers, 257 free sexual relations, vandalism committed by students, fights between students, consumptive economic life, and so on have become hot topics of discussion in the mass media, seminars, and on various occasions. This problem is exacerbated by the low level of public awareness of character education which harms children's attitudes. Children's attitudes are assessed by how they behave, what is said, and how they speak. A good child is a child who behaves according to religious norms, does not commit violence or even criminal acts (Maharani Ramadhanti, M Syarif Sumantri, 2019). Rachmah, (2013) said that the reason is that many experts in the field of morality and religion teach about morals but the behavior is not in line with the knowledge being taught. Since childhood, children are taught about honesty, courage, hard work, cleanliness, and cheating. Sadly, these virtues are taught only on paper and memorized as materials that must be studied. While character education is not limited to expensive exam questions but instead requires habituation. Habit to do good, to be honest, to be a knight, ashamed to cheat, ashamed to be lazy, ashamed to let the environment dirty. Nurhisam (2017) reported that character education is defined as education that develops character values in children so that they have values and character as their character, apply those values in their life, as members of society and religious, nationalist, productive, and creative citizens. Khamalah, (2017) said that the impact of character education is to build the nation's civilization. Character education is closely related to moral development. Character education problems are problems of morality, personality, and figure. Muslim \& Ranam, (2020) states that morals are the key to the rise of civilization or vice versa. If a nation can build good morals for its people, a good civilization will be formed that can advance the nation.

Putry, (2019) said that character can be considered the values of human behavior related to God Almighty, oneself, and fellow humans. Environment and nationality manifested in thoughts, words, and actions based on religious, legal, etiquette, culture, customs, and aesthetic norms. Samrin, (2016) said that along with this understanding, there are groups of people who argue that the good and bad of human character are innate since birth. If the innate soul is good, then the human will have good character, and vice versa if the innate soul is bad, then the human will have a bad character. Choli, (2020) explains that character education instills habits (habituation) about which things are good so that students understand (cognitively) what is right and wrong, can feel (affective) good values, and usually do it (psychomotor). This perceived character has three interrelated parts: moral knowledge, moral sense, and moral behavior. Meanwhile, according to Nurhisam, (2017) remark that character includes the whole of human nature in thinking, behaving, and behaving. Human behavior is inseparable from what he thinks and he also feels in his heart, so that a person's character needs knowledge of 
1595 Playing Football Creating Education Character In Youth Perspective In Nighborhood Environment Bahagia, Rimun Wibowo, Zulkifli Rangkuti, Zakky Muhammad Noor

DOI: https://doi.org/10.31004/basicedu.v5i3.934

kindness, then with the knowledge of goodness becomes the basis for thinking and also makes the feelings in his heart good, so that someone's behavior will be good because of the basis The knowledge and good feelings that he has obtained can direct the behavior he will do in his daily life.

Ahmad, (2015) said that the values that can be developed include curiosity, national spirit, love for the country, respect for preservation, friendship, love of peace, love to read, care for the environment, care for social and responsibility. Abdusshomad, (2020) remarked that the objectives of character education include character education, character education, moral education, value education, which are carried out consciously, systematically, and aimed at developing one's abilities so that they can decide and practice goodness in everyday life such as being responsible, honest, working. hard, and respect others. Meanwhile, Ismail, (2017) reported that the purpose of character education starts from forming the child's personality so that he becomes a good human being, a citizen, and a good citizen. Primasari et al., (2019) found that character education is very important as an effort to shape the character of the nation's generation who are not only skilled and intelligent but also have noble character. As for the criteria of good human beings, good citizens of society, and good citizens of a society or nation, in general, are certain social values that are heavily influenced by the culture of the community and nation. Santika (2020) reported that the success of character education is not necessarily seen from the perspective of the cognitive domain, but how is the balance between the cognitive, affective, and psychomotor domains.

Family, society, and school an inseparable units to form character. The family educates children's character in a limited environment. Meanwhile, the community also supports character building through various things, including the social environment, habits, culture, and others. This condition is experienced and carried out by individuals so that the person concerned will choose the path to form the character and character that is most expected following the wishes of the community itself (Kamil, 2015). So character is formed through a learning process in several places, such as at home and in the environment where they live. In this study, trying to find playing football creating a character education based on youth perspective in the neighborhood environment. This research is no longer looking for and re-examining the research that has been done. Several objectives will be expected to be found, starting from how to play football as character education for the younger generation related to teamwork, sportsmanship, honesty, and values of trust or responsibility as well as the behavior of taking a role in a position when playing football. Another goal is to find social capital in playing football starting from the benefits of social networking, solidarity, trusting, and social relationships between members of the team and opponents to support life. Finally, how social values play football so that it has an impact on the economy of the surrounding community.

\section{METHOD}

The research about playing football can create character education is held in youth in Neighborhood associations. The research method used is a qualitative descriptive approach. Descriptive research is a form of research that aimed to describe the phenomena that exist, whether a natural phenomenon or a man-made phenomenon. Descriptive research studying the problems in society, as well as the procedure applicable in the community including relationships, activities, attitudes, views, and processes, are ongoing and the effects of a phenomenon (Linarwati et al., 2016). Yuliani,(2019) said that qualitative descriptive research (QD) is generally used in social phenomenology. The main strength of qualitative research lies in the flexibility of the researcher's style to describe the research flow with a very open research problem. Harahap (2020) reported that mainly related to patterns and human behavior and what is behind these behaviors which are usually difficult to measure with numbers. Because the symptoms that appear are not always the same as what is in the mind and real desire.

Meanwhile, descriptive research can be defined as the research was conducted to provide an overview in more detail about a symptom or phenomenon. The result at the end of the research is usually typology or patterns regarding the phenomenon that is being discussed. Descriptive research is conducted by searching for 
information associated with existing symptoms, described clearly the goals to be achieved, plan how to do his approach, and collect a variety of kinds of data as materials for making the report (Priyono, 2016). To select the sample, the research uses purposive technique sampling. This sampling technique is implied because collecting the sample with some consideration including The head of the football team and members. The head of the football community is selected because they have participated in organizing several events like football acting and the person is mixed in playing football playing. Meaning that the person can be categorized as the person who has the widest knowledge and skill compared to another person in the member of the association group. However, members of the football team must be involved to have a variety of answers for research. There are several data that the researcher intent to gather such as about the question in connecting between character education in playing football, at least there is some aspect that the researcher would like to obtain such as playing football can stimulate teamwork, honesty, responsibility, role in society, and grow attitude like sportsmanship.

Furthermore, the researcher asks the question which is related to playing football has social capital value including it can build networking, trusting, solidarity, mutual assisting and social connection among the members in a group or group of a competitor. Another, researcher offer question about the advantage of playing football for improving health conditions such as heart attack, obesity, abolish the rate of human stress, and lung ailment. Lastly, the research asks about the connection of playing football for combating poverty or improve the economic circumstances of societies. The data which have been collected from in-depth-interview must be combined with another method like observation and documentation. Observation must be conducted because to see the location and the real action of cities. Once the data from some of the methods have been gathered, the data must be analyzed by triangulation data. Triangulation can be categorized as an analysis method to combine more than one method to obtain more reliable data including sources from in-depth-interview, documentation, and observation. Shidiq \& Choiri, (2019) said that triangulation can also be done by comparing the results of two or more researchers using different techniques. Data or information from one party must be checked for accuracy by obtaining the data from other sources, for example from second, third parties, and so on using different methods.

Shidiq \& Choiri, (2019) aim to compare information about the same thing obtained from various parties so that there is an assurance about the level of data confidence. This also prevents the danger of subjectivity. In this research, the researcher is assisted by other researchers to conduct the same interview as the original researcher to see the consistency of the respondents' answers to the questions asked by the researcher. Finally, synchronous data were obtained between in-depth interviews conducted by the researcher and other researchers who were instructed by the researcher to check the data in more depth. Even data collection is also carried out with differences in time (morning, daylight, and evening). The reason is that respondents are fresher in the morning so that the interviews were conducted at various times but the results still got the same answers. While the triangulation technique is to exert a variety of ways. In this research, the combination from numerous sources including in-depth-interview, observation, and documentation can be reliable data.

\section{RESULT AND DISCUSSION}

Playing ball can build good character for children because playing ball has character education values . After all, playing football can build social morals in the soul so that it can be mentally healthy. Playing ball also maintains physical health because playing football must maintain the health of the lungs, heart, and muscle condition. Playing soccer contains educational values, including playing football, having various kinds of rules that are applied in the field when you want to play. There are various roles of each player so that everyone has a contribution to struggle to maintain the team following the mandate that has been given. The role in playing football includes the role in a non-formal manner that is assigned to someone to carry out tasks in the game of football. Someone who acts as a keeper is responsible for guarding the goal from the opponent's attack. There 
1597 Playing Football Creating Education Character In Youth Perspective In Nighborhood Environment Bahagia, Rimun Wibowo, Zulkifli Rangkuti, Zakky Muhammad Noor

DOI: https://doi.org/10.31004/basicedu.v5i3.934

is even a change of roles in playing flexible so that the first role you have can switch to another role played by fellow teams so that there is a division of tasks for each person.

Each player has a role as a responsibility, including the keeper as a goalkeeper. There are several players in soccer including Back, midfielder, and attacker. Keever sends the ball to the back, then the ball is sent to the midfielder then the attacker kicks the ball to the opposing team. There are two midfielders, back there are four people and there can be more and one attacker. The attacker will be helped by a midfielder who moves towards the opponent. There is a very flexible swap position between team players. In this case, everyone has the same right to exercise the positions that have been owned by others. That way everyone who plays football activities can feel the difficulty and ease of the roles that have been played by others and continue to carry out that mandate. Meanwhile, exchanging roles is not easy because it is not certain that everyone's skills can be transferred to another. Even so, everyone has the opportunity to do a role that is not the first role he has. Someone who used to play as a back and midfielder will help someone who is struggling to become a striker to achieve common goals. When changing positions, there is learning that is gained, namely understanding one's position when occupying a position.

In children's education, role-playing is also often carried out. If children are involved in playing football, they will immediately experience a change of positions. In the end, they learned from an early age to carry out the mandate following the assigned task. This habit is a stimulus so that the behavior will be useful in his life someday. At the same time raises responsible behavior and avoids losing behavior to opponents because they are accustomed to implementing games in life. Children, when playing football, the roles of back, attacker, midfielder, and keeper belong to the responsibility that has been borne by the players who take part in this task. The success of the assigned task is not only for yourself so playing football is for the benefit of the group or team, not just individuals.

This relates to the role and responsibility of humans not only for the environment but when the mandate is not carried out then there is a divine affair because humans do not escape responsibility in the future to God. Furthermore, each task is also a mandate so that there are religious values in the work that is being accepted. Hermawan et al., (2020) mandate can also be said to be a form of professional attitude towards what God has given to all types of human professions. Several indicators can be used to measure responsibility including doing something that should be done, and planning, being persistent and always trying and doing your best, controlling yourself, and being disciplined, thinking before acting and considering consequences, being responsible for your words., actions, and attitudes and setting good examples for others (Siburian, 2012). Anwar, (2014) said that the responsible ability built through the education process includes vertical responsibility (to God), horizontal responsibility (to outside himself,) and personal responsibility.

Another value that can be used to build character is the honesty of children. When playing football, each player is being tested for honesty. For example, when playing, a player as a ball does not need to tell the referee about the mistakes he made during a match. When the player himself approaches the referee and says about the mistakes he has done, he is classified as an honest player. The habit of acknowledging a behavior that is done is classified as wrong can foster individual honesty and awareness of the mistakes that have been made. Honesty is also built through the referee, when the referee sees the referee himself immediately follows up on the actions of the players. The result of learning honesty will be permanent behavior if it is applied to children. Honesty must be formed and conditioned to behave honestly by often being involved in games such as soccer because honesty in the game of football includes direct multi-location testing.

However, when a player does not want to be honest and silent, including that player needs recognition from other people that he is not being honest so that the public or the players who witnessed it and the referee who becomes the witness. Playing soccer also has an impact on sportsmanship. Sports behavior can be seen when a player commits a violation, but other teams never get angry or their emotions increase at the time of the incident but leave the referee as the person who is considered to be able to solve the problem. The team can 
reply but they don't. They are more accepting of defeat in playing football than angry because they lose when playing soccer. Even when a soccer match is finished, it's like enemies breaking and hurting when playing soccer but once finished playing they don't raise problems when the game has passed. All teams remain friends outside the match, greet each other, and smile at each other and as if nothing happens to hurt feelings and souls. They think that something that happens during a ball match does not need the problem to be done again outside the match.

These findings are supported by various opinions like Pradipta,(2015)reveals that sportsmanship is a mental attitude that shows dignity in sports. The value of sportsmanship underlies the formation of attitudes and attitudes that underlie behavior. As a moral concept, sportsmanship contains respect for the opponent as well as self-respect that is related between the two parties seeing their opponent as a partner and integrating sportsmanship with the concept of friendship. Yuliawan, (2016) said that the spirit of sportsmanship is admitting defeat, respecting opponents, and enforcing fair play, and being able to reward himself and others. Zhannisa, (2015) reported that with sportsmanship, individuals or groups were knightly, gentle, and honest in playing. In this understanding, players are fair and open, do not commit cheating and certain tricks against their opponents. Sportsmanship upholds honesty as a benchmark, as well as the principle of healthy and quality competition. Theories and findings in the field can be interpreted as a sporty spirit, namely, a soul that controls emotions both verbally and in visible behavior so as not to hurt feelings and cause noise in the game and outside the match. This happens because there is a high enough awareness of each member to respect the opponent and fully aware that they are in a match.

Furthermore, any event at the match will not have an impact on the association of the team and members in everyday life outside the match. A sporty spirit is instilled from an early age in children, especially elementary school children, can increase patience so that they are not easily ignited and respect friends and do not want to have conflicts. Herdiyana \& Prakoso, (2016) reveal that sportsmanship will not be detrimental to others and will be beneficial for themselves and trust will be a big mandate for a sporty student, while a sporty student can be relied on when gaining trust. Children's participation in soccer games from an early age can stimulate children to become sportsmen in the future so that they need to be cultivated from an early age. Meanwhile, habituation is one of the means in education. Character is composed of our habits because they are consistent, often have unconscious patterns, these habits are constantly, every day revealing our character (Rohendi, 2018).

Besides that, teamwork in the game of soccer is so solid that playing football is impossible to do alone. Teamwork is work hand in hand, helping to help mutually beneficial between one part and another (Arizona, 2018). When achieving common goals, teamwork by forming each team and the task becomes part of realizing work not for its interests but working for the goals that have been achieved. As well as to hone togetherness to attack your opponent. The roles of the back, Keever, arena, attacker, referee, and youth organizations are inseparable parts of achieving the desired achievement for the common interest, not for individuals. When playing football, each individual can't work alone so that the skills and knowledge of each individual in the team will determine the strength to fight against the opponent. Msulihah (2016) said that teamwork can be called a group of intelligent people who meet the requirements of the fulfillment of the understanding so that synergies are formed between various activities to carry out activities to achieve the best performance.

The steps for teamwork management include: determining the goals and objectives of the teamwork, specifying the tasks for each team, and providing motivation. Before the match starts, each individual, according to their skills, will be arranged first so that each role in the match has been carried out. The coach also has an important role to play in igniting the fighting spirit of the soccer players so that the spirit ignites in each player. Values in children's education, that is, if children are involved in soccer activities, they have been given instructions to live and cannot be alone. This life cannot possibly need any other person. That way a child who is used to working in a team will make the team an asset in moving through life. This finding is related to building children's character, especially to play a role. Playing soccer and exercising, in general, includes 
building physical health. Setiyawan M.Or,(2019) reported that sport is a fundamental basis and philosophy of life that reflects and combines the balance between the body (a healthy body) and the spiritual (will, morals, and intelligence).

Coupled with the arrangement of exercises before playing because the player doesn't overdo the muscles. So there is no overlap in training, then you cannot play. So the exercise time should be set around 1 hour per day and not every day of the week. The amount of exercise just 5 days per week is quite a lot. Playing football is also related to heart health, so if your breath is not in a good condition, your heart will also not improve. If they continue, then when they play there will be an impact on injuries to parts of the body. In training, the ball must be reviewed to ensure that someone is fit or not to participate in the ball match. With sports activities such as football, it can improve health conditions so that a person becomes fitter in life and while playing. Sudiana, (2019)remarked that physical fitness meant a change in physical condition for the better, especially in the heart, lungs, and blood vessels. Meanwhile, spiritual satisfaction during sports activities can pleasure itself. Other health values include preventing obesity, stress, diabetes, hyperlipidemia, stroke, heart disease, and hypertension (Andalasari \& Berbudi BL, 2018).

Other values that can be taken from playing football are the mutual help that starts with one team when playing football. For example, the football team helped his deceased relative, starting by providing tents, bathing corpses, and also ordering benches to prepare to take care of the corpses. This information is usually shared in the what's app team groups so that each member can participate directly in building solidarity between members. As well as helping each other when there are prayers and tahlilan for people who have passed away. Other life values, with football in one team, each member in the team will share information starting from information on work opportunities to build social networks. Members of the team can work because of an acquaintance from the team who helps to find work.

In addition to information about work, members of the team can also get information opportunities about college. Even members of the team learn together and share information about class assignments outside the game. Social networks are also formed in soccer-playing teams because playing football matches is usually done based on regional or regional levels. Playing football at the lowest level is carried out at the neighborhood and community groups, continued in the sub-district and even at the district and national levels. In each of these areas, there will be social relationships with opposing teams in various locations to allow more friends and networking. These results are related to social capital, namely social networks. Other findings show that playing sports can build friendship and social relationships in groups or fellow teams, opponents, and the wider community who are watching the match. Meanwhile, social relationships/interactions between community members can foster brotherhood, kinship, and kinship (Solikatun \& Juniarsih, 2018). The interaction between members in the soccer player group is also very intensive because there are frequent meetings such as during practice and matches.

This fact is supported by Gustarini \& Hidayah, (2018)said that the interaction between individuals in a social group if it occurs over a long time occurs intensively and sustainably, will automatically foster a sense of solidarity due to similarities. Sports can build relationships across social, economic, and cultural differences in society (Indrawan \& Aji, 2019). Conditions supported by Perdana, (2018)reported that football can be a very useful socio-political tool, namely as a unifying medium, to deliver messages or information about peace to be conveyed to a wider audience. It's just that there is ugliness from social networks such as being a source of division due to not being able to accommodate more members' interests (Teguh, 2017). Then, playing bole can build a high level of trust among members. Faedlulloh, (2015)said that this mutual trust grows and is rooted in the values inherent in group culture. Suppose the team entrusts money to the treasurer. All teams believe because every use of money is always transparent so that each member can see the evidence. In addition, the funds for playing football are entrusted to the treasurer so that the treasurer has the trust or trust of each member. 
The most confidence in the football team is not built easily. While members have entrusted their trust to the treasurer to take care of financial matters where the money does not belong to them but belongs to the public, namely members. Syafar (2017) reported that trust will occur if it is based on the values of honesty, fairness, openness, mutual care, mutual respect among these communities. Trust will emerge when all members of the community have strong social ties that are built into the social system if the members interact with each other for a relatively long and deep time. Meanwhile, Hastanti \& Purwanto, (2019) utter that trust will create social obligations. Trusting someone will bring back the person's trust (reciprocity). In reciprocity, there are repaid and balanced. In addition, according to Aditya, (2018), it is reported that trust between community members functions like a lubricant that makes the running of the community or organization more efficient. This condition is also supported by Cahyono \& Adhiatma, (2016) where trust is an expectation of order, honesty, and cooperative behavior that emerges from within a community based on the norms shared by its members.

Each member of the team in a game group football will trust back in the treasurer as the holder of finances because they have never been cheated, especially in terms of allotment of funding. Playing football also never shows the status (a student, a worker, an official, or any other position). The players don't look at the status of each player, they look more at the skills when playing football. Of course, there is no social description, everyone with any status has the same opportunity to become a human who has skills in playing football. Finally, playing football matches can bring livelihoods for soccer players because there is a prize when the match is won by a team. The local community can also get sustenance from the competition because they have the opportunity to trade various types of food and drinks. Directly, the game matches at the village, such as matches at the village level, provide economic access for the surrounding community. Unfortunately, playing football or sports is not given enough attention because being busy at work makes a person does not have enough time to exercise. Meanwhile, the quality of human resources such as youth is very supportive of the development of a nation. Even though youth have a role to play in building the nation.

\section{CONCLUSION}

Numerous points of view can be concluded from the research result above including character education can be performed from playing football including teamwork because when the youth participate in playing, they must complete the task-based collectively instead of individually because they need the other individual skill and knowledge to tighten the power of team. The other is playing football is one method to applicate the alteration of roles in playing. In a football competition, many positions must be assumed by the players involved, starting from the goalkeeper, back, arena and attacker. When the game progresses, the player who is trusted to be the back and arena can become an attacker or switch positions. Exchange of positions like this gives a value to the player that when the position in the team is accepted, the player must do it correctly and responsibly. At the same time, there are mandate values from playing football because each role cannot leave a mandate. Every individual who is accustomed to being assigned a mandate since childhood and is responsible for what is given to youth has the possibility of becoming a human being who maintains his trust in the future.

In addition, playing football can build honesty because in playing there must be violations committed. When youths who play admit mistakes that have been made to the referee, this includes behavior to build honesty without having to say the referee. If this value continues to be nurtured from childhood, it can shape honest behavior one day. Then, playing football is the same as building social capital because playing football is done at the village and district level so that players have many acquaintances from various groups. This condition makes the team have a strong social network so that it is useful for navigating life. After that there is trusting value, there is financial management carried out by the treasurer in the team. In this condition, the treasurer is learning to build trust in all teams through financial transparency so that all trust the team. Another social capital, namely playing football, means fostering helping behavior because the team will help every member who feels troubled in life. 
As well as being a center of information for each member starting from job information, education information, and life information in a broad sense due to solidarity has been well developed. Even in playing football, regardless of status, every player is considered the same even though they come from various groups. This proves that there is no discrimination in the game of football and it is valuable for individuals to eliminate souls who like to discriminate against others. In addition, a good character must be built from physical health. The game of football plays a role in maintaining health starting from a healthy heart, lungs, eliminating obesity and high blood pressure. When playing, it must be checked about health, when not fit, the player is prohibited from competing. Finally, the game of football has an economic impact on all residents around the match. People have the opportunity to trade all food and beverages.

\section{REFERENCES}

Abdusshomad, A. (2020). Pengaruh Covid-19 terhadap Penerapan Pendidikan Karakter dan Pendidikan Islam. QALAMUNA: Jurnal Pendidikan, Sosial, Dan Agama, 12(2), 107-115. https://doi.org/10.37680/qalamuna.v12i2.407

Aditya, Z. F. (2018). Penerapan Modal Sosial Dalam Praktek Peradilan Yang Berbasis Kepekaan Sosial. Jurnal Ilmiah Hukum LEGALITY, 25(2), 200-219. https://doi.org/10.22219/jihl.v25i2.6002

Ahmad, T. A. (2015). Kendala Guru dalam Internalisasi Nilai Karakter pada Pembelajaran Sejarah. Khazanah Pendidikan, VIII(1), 1-15.

Andalasari, R., \& Berbudi BL, A. (2018). Kebiasaan Olah Raga Berpengaruh Terhadap Tingkat Stress Mahasiswa Poltekkes Kemenkes Jakarta Iii. Jurnal Ilmu Dan Teknologi Kesehatan, 5(2), 179-191. https://doi.org/10.32668/jitek.v5i2.11

Anwar, S. S. (2014). Tanggung Jawab Pendidikan Dalam Perspektif Psikologi Agama. Psympathic: Jurnal Ilmiah Psikologi, 1(1), 11-21. https://doi.org/10.15575/psy.v1i1.463

Arizona, R. (2018). Peran Team Work Dalam Upaya Meningkatkan Kinerjakaryawan Pada Pt. Asuransi Sinarmas Cabang Malang. Aplikasi Administrasi: Media Analisa Masalah Administrasi, 20(1), 52-60. https://doi.org/10.30649/aamama.v20i1.92

Cahyono, B., \& Adhiatma, A. (2016). Peran Modal Sosial Dalam Peningkatan Kesejahteraan Masyarakat Petani Tembakau Di Kabupaten Wonosobo. Conference In Business, Accounting, And Management (CBAM), 1(1), 131-144.

Choli, I. (2020). Problematika Pendidikan Karakter Pendidikan Tinggi. Tahdzib Al-Akhlaq: Jurnal Pendidikan Islam, V(1), 57-72. https://doi.org/10.34005/tahdzib.v3i1.831

Faedlulloh, D. (2015). Modal Sosial Dalam Gerakan Koperasi. IJPA (The Indonesian Journal of Public Administration), 2(1), 1-20.

Gustarini, E., \& Hidayah, N. (2018). Solidaritas Komunitas Suporter PSS Sleman PATBOIS di Desa Patukan Gamping Sleman. E-Societas, 7(1).

Hastanti, B., \& Purwanto, P. (2019). Analisis Modal Sosial Dalam Pengelolaan Mata Air Di Dusun NgaramAram, Desa Crewek, Kecamatan Kradenan, Kabupaten Grobogan (Analysis of social capital in springs management at Ngaram-aram Hamlet, Crewek Village, Kradenan District, Grobogan Regency). Jurnal Penelitian Pengelolaan Daerah Aliran Sungai, 3(2), 89-110. https://doi.org/10.20886/jppdas.2019.3.2.89-110

Herdiyana, A., \& Prakoso, G. P. W. (2016). Pembelajaran Pendidikan Jasmani Yang Mengacu Pada Pembiasaan Sikap Fair Play Dan Kepercayaan Pada Peserta Didik. Jurnal Olahraga Prestasi, 12(1), 77-85. https://doi.org/10.21831/jorpres.v12i1.9498

Hermawan, I., Ahmad, N., \& Suhartini, A. (2020). Konsep Amanah dalam Perspektif Pendidikan Islam. QALAMUNA: Jurnal Pendidikan, Sosial, Dan Agama, 12(2), 141-152.

https://doi.org/10.37680/qalamuna.v12i2.389 
1602 Playing Football Creating Education Character In Youth Perspective In Nighborhood Environment Bahagia, Rimun Wibowo, Zulkifli Rangkuti, Zakky Muhammad Noor

DOI: https://doi.org/10.31004/basicedu.v5i3.934

I Wayan Eka Santika. (2020). Pendidikan Karakter pada Pembelajaran Daring. Indonesian Values and Character Education Journal, 3(1), 8-19.

Indrawan, J., \& Aji, M. P. (2019). Olahraga sebagai Sarana Pemersatu Bangsa dan Upaya Perdamaian Dunia [Sports as an Instrument of Unifying a Nation and Achieving World Peace]. Verity: Jurnal Ilmiah Hubungan Internasional (International Relations Journal), 10(20), 69-86. https://doi.org/10.19166/verity.v10i20.1459

Ismail, M. (2017). Menelusuri Konsep Pendidikan Karakter dan Implementasinya di Indonesia. Journal of Chemical Information and Modeling, 1(1), 1-17.

Jahroh, W. S., \& Sutarna, N. (2016). Pendidikan Karakter Sebagai Upaya Mengatasi Degradasi Moral. Prosiding Seminar Nasional Inovasi Pendidikan, 395-402.

Kamil, G. (2015). Pembentukan Karakter Melalui Pendidikan Sosiologi. Tingkap, XI(1), 54-66.

Khamalah, N. (2017). Penguatan Pendidikan Karakter di Madrasah. Jurnal Kependidikan, 5(2), 200-215. https://doi.org/10.24090/jk.v5i2.2109

Laksana, S. D. (2015). Urgensi Pendidikan Karakter Bangsa Di Sekolah [Urgency of National Character Education In Schools]. MUADDIB, 05(01), 167-184.

Linarwati, M., Fathoni, A., \& Minarsih, M. M. (2016). Studi Deskriptif Pelatihan Dan Pengembangan Sumberdaya Manusia Serta Penggunaan Metode Behavioral Event Interview Dalam Merekrut Karyawan Baru Di Bank Mega Cabang Kudus. Journal of Management, 2(2), 1-8.

Maharani Ramadhanti, M Syarif Sumantri, E. (2019). Pembentukan Karakter Dalam Pembelajaran Bcct (Beyond Center And Circle Time). Jurnal Educate, 4(1), 9-17.

Muslim, I. F., \& Ranam, S. (2020). Pendidikan Kedisiplinan Di Pondok Pesantren El Alamia Untuk Menanggulangi Degradasi Moral. Research and Development Journal of Education, 102-109. https://doi.org/10.30998/rdje.v1i1.7325

Nurhisam, L. (2017). Implementasi Pendidikan Karakter Sebagai Solusi Dekadensi Moral Anak Bangsa. Elementary, 5(1), 110-131.

Perdana, K. E. (2018). Sepakbola Sebagai Media Solidaritas Politik Bagi Supporter Indonesia. Jurnal Ilmu Politik Dan Komunikasi, 8(2), 1-9. https://doi.org/10.34010/jipsi.v8i2.1269

Pradipta, G. D. (2015). Sportifitas Dalam Keolahragaan Sebagai Bagian Pembentukan Generasi Muda Dan Nasionalisme Oleh Galih Dwi Pradipta. Jurnal Ilmiah CIVIS, V(1), 713-724.

Primasari, D. A. G., Dencik, \& Imansyah, M. (2019). Pendidikan Karakter Bagi Generasi Masa Kini. Prosiding Seminar Nasional Pendidikan Program Pascasarjana Universitas Pgri Palembang 12 Januari 2019.

Priyono. (2016). Metode Penelitian Kuantitatif. Sidoarjo: Zifatama Publishing.

Putry, R. (2019). Nilai Pendidikan Karakter Anak Di Sekolah Perspektif Kemendiknas. Gender Equality: International Journal of Child and Gender Studies, 4(1), 39-54. https://doi.org/10.22373/equality.v4i1.4480

Rachmah, H. (2013). Nilai-Nilai dalam Pendidikan Karakter Bangsa yang Berdasarkan Pancasila UUD 1945. E-Jurnal Widya Non-Eksakta, 1(1), 1-14.

Rohendi, E. (2018). Mengembangkan Sikap Dan Perilaku Anak Usia Dini Melalui Pendidikan Berbasis Karakter. Cakrawala Dini: Jurnal Pendidikan Anak Usia Dini, 3(1), 1-9. https://doi.org/10.17509/cd.v3i1.10318

Samrin. (2016). Pendidikan Karakter (Sebuah Pendekatan Nilai). Jurnal Al-Ta'dib, 9(1), 120-143.

Setiyawan M.Or. (2019). Visi Pendidikan Jasmani dan Olahraga. Jurnal Ilmiah PENJAS, 3(1), 74-86.

Shidiq, U., \& Choiri, M. (2019). Metode Penelitian Kualitatif di Bidang Pendidikan. In Journal of Chemical Information and Modeling. 
1603 Playing Football Creating Education Character In Youth Perspective In Nighborhood Environment Bahagia, Rimun Wibowo, Zulkifli Rangkuti, Zakky Muhammad Noor

DOI: https://doi.org/10.31004/basicedu.v5i3.934

Siburian, P. (2012). Penanaman dan Implementasi Nilai Karakter Tanggung Jawab. Generasi Kampus, 5(1), $85-102$.

Siswanti, Utomo, C. B., \& Muntholib, A. (2018). Implementasi Pendidikan Karakter dalam Membentuk Sikap dan Perilaku Sosial Peserta Didik Melalui Pembelajaran Sejarah di SMA PGRI 1 Pati Tahun Pelajaran 2017/2018. Indonesian Journal of History Education, 6(1), 1-13.

Solikatun, \& Juniarsih, N. (2018). Modal Sosial Sebagai Srategi Bertahan Hidup Masyarakat Desa Maria, Kecamatan Wawo, Kabupaten Bima, Provinsi Nusa Tenggara Barat. Jurnal Analisa Sosiologi, 7(2), $262-$ 273.

Sudiana, I. K. (2019). Dampak Olahraga Wisata Bagi Masyarakat. Jurnal IKA, 16(1), 55-66. https://doi.org/10.23887/ika.v16i1.19826

Suryadi, B. (2012). Pendidikan Karakter: Solusi Mengatasi Krisis Moral Bangsa. Nizham, 4(2), 72-84.

Teguh, T. dkk. (2017). Membangun modal sosial pada gabungan kelompok tani Building social capital for farmer association. Jurnal Masyarakat, Kebudayaan Dan Politik, 30(1), 59-67.

Wahidin, U. (2017). Pendidikan Karakter Bagi Remaja. Edukasi Islami : Jurnal Pendidikan Islam, 2(3), 256269. https://doi.org/10.30868/ei.v2i03.29

Yuliani, W. (2019). Metode Penelitian Deskriptif Kualitatif Dalam Perspektif Bimbingan dan Konseling. Quanta, 2(2), 83-91.

Yuliawan, D. (2016). Pembentukan Karakter Anak Dengan Jiwa Sportif Melalui Pendidikan Jasmani Olahraga dan Kesehatan. Jurnal Sportif, 2(1), 101-112. https://doi.org/10.29407/js_unpgri.v2i1.661

Zhannisa, U. H. (2015). Implementasi Nilai - Nilai Olahraga dalam Pembangunan Nilai Kewarganegaraan dan Memperkokoh NKRI. Jurnal Ilmiah CIVIS, V(2), 865-878. 